Аннотация: Авторы анализируют жизнь, деятельность и взгляды несправедливо забытой личности словацкой культурной истории - Самуила Ферьенчика, священника, писателя, публициста, метеоролога, помолога, друга Я. Коллара и знакомого И.В. Гете. В статье рассматривается его личность в аспекте тогдашнего культурного контекста. Внимание авторов концентрируется также на спорных аспектах его жизни, а именно на его участии в споре о штуровском варианте литературного словацкого языка, на его выступлении против манифеста Й.М. Гурбана «Братья словаки» и на его деятельности во время Словацкого национального восстания 1848-1849 гг. Авторы стремятся к справедливой оценке его взглядов, учитывая ценностное разнообразие современной культурной элиты и поколенческую специфику.

Ключевые слова: Самуил Ферьенчик, Ян Коллар, Иоганн Вольфганг Гете, Людовит Штур, Йозеф Милослав Гурбан

M. Braxatoris, A. Braxatorisová (Slovak Republic, Trnava)

\title{
Activity of Samuel Ferjenčík (1793-1855) in the Cultural-historic Context
}

Abstract: The authors analyze the life, activities and views of an unfairly forgotten person in Slovak cultural history: Samuel Ferjenčík, priest, writer, publicist, meteorologist, pomologist, friend of J. Kollar and acquaintance of I.V. Goethe. The article examines his personality in the aspect of the contemporary cultural context. The authors' attention is also focused on the controversial aspects of his life, namely on his participation in the dispute about the Stúr's variant of the literary Slovak language, on his speech against the manifesto of J.M. Hurban "Brothers Slovaks" and on his activities during the Slovak National Uprising of 1848-1849. The authors strive for a fair assessment of his views, taking into account the value diversity of the contemporary cultural elite and generational specifics.

Key words: Samuel Ferienčík, Ján Kollár, Johann Wolfgang Goethe, Ludovít Štúr, Jozef Miloslav Hurban 
Самуил Ферьенчик (1793-1855) был словацким евангелическим священником, писателем, публицистом, метеорологом, помологом и пропагандистом просвещения. Богословское образование он получил в Братиславе, с 1816 по 1818 г. продолжал изучать теологию в Йенском университете, где посещал лекции Лоренца Окена по естественной философии, лекции Генриха Людена по философии, политической теории и естественному праву, а также лекции по естественным наукам, особенно по минералогии и астрономии. В Йене он получил диплом внешнего действительного члена Общества по всей минералогии и его секретаря от венгерского народа. В 1818 г. он был рукоположен в священники, затем служил капелланом и пастором. С 1827 г. он жил в Елшаве, где проработал до самой смерти. С 1836 г. служил в качестве гемерского консеньора, а с 1853 г. - в качестве сеньора. В 1842 г. он был участником делегации, которая представила австрийскому императору «Словацкий престольный просбопис» - петицию за изменение национальных условий в Венгрии. В качестве посланника Евангелической церкви Потисского дистрикта он присутствовал на общих собраниях Общества Густава Адольфа в 1851 г. в Мамбурге и в 1852 г. в Висбадене. Его вдова Луиза Ферьенчик в 1864 г. основала и продолжала руководить Елшавским гуманитарным женским обществом, которое, вероятно, было первым женским обществом в Словакии («Живена» была основана только в 1869 г.). Ферьенчик в более широких кругах был известен как «елшавский пророк погоды»; в связи с этим он появляется также в стихотворении известного венгерского поэта Яноша Араньи «Népnevelés» («Воспитание народа») $1855 \Gamma^{1}$

\section{ДРУЖБА С ЯНОМ кОЛЛАРОМ}

После окончания учебы в Братиславе Ферьенчик дополнил свои богословские знания в известном университете в Йене, где в то самое время учились Павел Йозеф Шафарик, Ян Коллар и Ян Халупка. По его собственным словам, 3 октября 1816 г. приехал в Йенский университет, где среди других соотечественников «также нашел наших дорогих земляков, Шафарика и Халупку» ${ }^{2}$. В связи со встречами в Йене с И.В. Гете Ферьенчик упоминает своего «верного друга Коллара» ${ }^{3}$. При этом он ссылается на слова Коллара в толковании «Дочери Славы», согласно которым Коллар обязан Ферьенчику знакомством с Гете ${ }^{4}$. Эти слова представляют собой толкование стихов, в которых Коллар помещает Ферьенчика в «Лете», славянское небо:
Hleděla i na Seberiniho,
Palackého, Koiše, Pačiče,
Ferjenčjka jsem a Suchaniho:
Wšecky matka třjmá za swé děti,
Wšak co slastj gich se dotýče,
To zde nechci swětu wyzwáněti ${ }^{5}$.

\footnotetext{
${ }^{1}$ Arany J. Arany János elbeszélő költeményei. Első kötet. Toldi. Budapest, 1883. O. 301-303.

${ }^{2}$ Ferjenčik S. Zlomka z Meteorologie. // Domová pokladňica kalendár na rok prjestupní 1848. Vidáva Daniel Lichard. Ročňík druhí. Skalica, [1848]. S. 54.

${ }^{3}$ Ferjenčik S. Zlomka z Meteorologie. S. 55.

${ }^{4}$ Kollár J. Wýklad čili Přjmětky a wyswětliwky ku Sláwy dceře. W Pešti, 1832. S. 351-352.

${ }^{5}$ Kollár J. Sláwy dcera. W Pešti : tiskem Trattnera a Károliho, 1832, sonet 462, s. p.; Kollár J. Díla básnická Jana Kollára we dwau djljch. W Budíně, 1845, sonet 466, s.p.; Kollár J. Dielo I.. Bratislava, 2001, znelka 479, s. 282.
} 
Упомянутые обстоятельства описывает в связи со знакомством с патриархом немецкой литературы также биограф Коллара Вацлав Зеленый, называющий Ферьенчика другом Коллара ${ }^{1}$.

Ферьенчик подписался на несколько произведений Яна Коллара, в том числе на сборник «Národnie spievanky» («Национальные песни»), и даже собирал для него народные песни и отправлял их емуㄹ․ Их взаимная связь также очевидна из позиции Ферьенчика в полемике о литературном языке и из переписки Коллара в связи со «Словацким престольным просбописом» (обе см. ниже).

\section{ИОГАНН ВОЛЬФГАНГ ГЕТЕ}

Ферьенчик очертил свое знакомство с немецким писателем И.В. Гете в календаpe «Domová pokladnica» («Домашяя казна») за 1848 г., где он описал встречу с Гете в доме барона Кнебеля, сближение через пение и игру на гитаре, разговор о минералогии и получение диплома минерологического общества ${ }^{3}$. Позже он упоминает прощальный подарок Гете (книга «Герман и Доротея» с его собственным посвящением) и разговор о приближающейся грозе, который стал толчком для его последующего интереса к метеорологии ${ }^{4}$. Упомянутые события указаны также в более поздних биографических источниках ${ }^{5}$ Ферьенчик детально передал слова Гете в судьбоносном разговоре о предсказании грозы в «Орле Татранском» в 1847 г.

\section{«С ЛОВАЦКИЙ ПРЕСТОЛЬНЫЙ ПРОСБОПИС»}

Ферьенчик вошел в историю словацкого национального движения как подписант и участник делегации «Словацкого престольного просбописа» - выступления словацкой (церковной и светской) интеллигенции против мадьяризации, адресованного австрийскому императору Фердинанду $\mathrm{I}^{7}$. Петицию подписали суперинтенданты Павел Йозеффи и Ян Себерини, профессор Юрай Палкович, пасторы Ян Халупка, Самуил Ферьенчик и Михал Годжа, а также 200 других пасторов, профессоров и школьных учителей. Суперинтенданта Йозеффи убедил принять участие в руководстве делегацией Людовита Штура, который также выбрал других ее членов: Яна Халупку, Самуила Ферьенчика и Михала М. Годжу ${ }^{8}$, и они в июне 1842 г. под руководством Йозеффи приняли участие в послании в Вене. Й.М. Гурбан объясняет участие Ферьенчика следующим образом: «Ферьенчик был фигурой, созданной для репрезентации, превосходным оратором, он всегда ходил в рясе, нося образ священника истинной "militantis ecclesiae" (борющейся церкви; примеч. авторов. - М.Б., А.Б.), высокая фигура, закаленная в постоянной

${ }^{1}$ Zelený $V$. Jan Kollár. Máj: almanah na rok 1862. Praha: I.L. Kober, 1862. S. 17

${ }^{2}$ Demmel J. Rok 1848 a Slováci. // Rozštiepená minulost'. Kapitoly z histórie Slovákov a Mad’arov. Budapest, 2008. S. 78; 86, pozn. 9 и указанные там источники.

${ }^{3}$ Ferjenčík S. Zlomka z Meteorologie. S. 55.

${ }^{4}$ Ferjenčík S. Zlomka z Meteorologie. S. 56.

${ }^{5}$ См., напр.: Biographisches Lexikon des Kaiserthums Oesterreich. Vierter Theil. Wien, 1858. S. 186-187; Szinnyei J. Magyar írók élete és munkái a Magyar Tudományos Akadémia megbizásából 3. köt. Fa-Gwóth. Budapest, 1894. Col. 424; Schröer K.J. Goethe und ein Candidat der Theologie aus Ungarn // Chronik des Wiener Goethe-Vereins. 1889. №2. S. 7-11 (Шреер опубликовал также факсимиле и транскрипции ряда документов, в том числе посвящения «Германа и Доротеи» и диплома Ферьенчика, члена и секретаря Минералогического общества, подписанного И.В. Гете, и др.).

${ }^{6}$ Orol Tatranskí. Т. 2. 1846-1847. № 52. S. 414. К.Ю. Шреер воспроизводит этот разговор с некоторыми отличиями; см. Schröer K.J. Goethe und ein Candidat der Theologie aus Ungarn. S. 285-286.

${ }^{7}$ CM.: Rapant D. Slovenský prestolný prosbopis z roku 1842. 2. diel. Dokumenty. Liptovský Sv. Mikuláš 1943. S. 337-347.

${ }^{8}$ Botto J. Michal M. Hodža. Životopisný nákres. Turčiansky Sv. Martin, 1911. S. 21; Botto J. Slováci: vývin ich národného povedomia: dejepisný nákres. Turčiansky Sv. Martin, 1906. S. 55. 
борьбе с гемерскими мадьяронами» ${ }^{1}$. Сам Людовит Штур характеризует суперинтендентов Йозеффи и Себерини, Яна Халупку, Михала Годжу, Самуила Ферьенчика, Яна Чапловича и других как «лучших мужей протестантизма» ${ }^{2}$. С периода подготовки и самого послания сохранилось множество упоминаний о Ферьенчике во взаимной переписке Йозеффи и Яна Коллара ${ }^{3}$, а также других важных исторических документов ${ }^{4}$.

\section{СПОР О ШТУРОВСКОМ ВАРИАНТЕ ЛИТЕРАТУРНОГО СЛОВАЦКОГО ЯЗЫКА}

Своим вкладом в сборник Коллара «Голоса о необходимости единства литературного языка для чехов, мораван и словаков» Ферьенчик попытался вмешаться в языковые споры о штуровском варианте словацкого литературного языка 5 . Он хвалил именно содержание и цели «Словацкой национальной газеты» Штура, однако выразил обеспокоенность тем, что ее цель разрушит «диалект самогонщиков», на котором она написана ${ }^{6}$. В связи с этим он подробно излагает свои возражения против «штуровщины», звучащие в духе критики Колларом данного варианта литературного языка 7 . Однако в то же время, когда Ферьенчик выступал против литературного словацкого языка, он начал писать в «Словацкую национальную газету» Штура статьи-на штуровском варианте литературного языка. На этом варианте литературного языка Ферьенчик опубликовал статьи в «Словацкой национальной газете» (т. I.-III, 1845-1847), «Орле татранском» (т. I, 1845-1846, № 16, 18, 27, 33; т. II, 1846-1847, № 36, 44, 52, 60, 61; т. III, 1847-1848, № 68) и «Домашней казне» (т. II, 1848 и др.). Кажется, что национальные вопросы, занимавшие важное место в его рейтинге приоритетов, тем не менее уступали место другим (просветительским, церковным и т. д.) интересам. Выступление Ферьенчика против новой формы литературного языка не повлияло на отношение к нему Людовита Штура ${ }^{8}$, который почтительно его поприветствовал в сноске, когда была опубликована его первая статья в «Словацкой национальной газете»9.

\section{Л И Т РАТ УРНОЕ ТВОРЧЕСТВО}

Литературное творчество Ферьенчика еще не получило должной оценки и исследования, несмотря на его неоспоримые литературно-эстетические и интеллектуальные качества и авторскую литературную (особенно гомилетическую) продуктивность. Он был автором нескольких печатных проповедей по поводу пожара в Елшаве; конвента гемерской церкви, начала работы Сама Томашика приходским священником в Хижнянах, основания церковной башни в Елшаве, освящения еван-

${ }^{1}$ Hurban J.M. Ludovít Štúr. (Pokračovanie.) // Slovenské Pohl'ady. 1882. №3. S. 263.

${ }^{2}$ Hurban J.M. Ludovít Štúr. (Pokračovanie.). S. 145.

${ }^{3}$ Rapant D. Slovenský prestolný prosbopis z roku 1842. 2. diel. S. 335; Hurban J.M. L'udovít Štúr. (Pokračovanie.) // Slovenské Pohl'ady. 1882. №3. S. 267-268; Chlebuš P. Samuel Ferienčík známy slovenský národný činitel'// Vlastivedné štúdie Gemera č. 4. Martin, 1986. S. 133-134.

${ }^{4}$ Rapant D. Slovenský prestolný prosbopis z roku 1842. 2. diel. S. 443-445; 467-468 и др.

${ }^{5}$ Ferjenčík S. XXVIII. Slowo lásky ku Břetislawským Nowinám // Hlasowé o potřebě jednoty spisowného jazyka pro Čechy, Morawany a Slowáky. W Praze, 1846. S. 214-216.

${ }^{6}$ Ferjenčík S. XXVIII. Slowo lásky ku Břetislawským Nowinám. S. 214.

${ }^{7}$ Cp., напр.: Kollár J. B) Odpowěd' Jana Kollára na psaní Ludewíta Štúra ode dne 7 Unora 1846 // Hlasowé o potřebě jednoty spisowného jazyka pro Čechy, Morawany a Slowáky. W Praze, 1846. S. 140; 147-148; $166-167$.

${ }^{8}$ Cp. Chlebuš P. Samuel Ferienčík známy slovenský národný činitel'. S. 136

${ }^{9}$ «S úctou vítame tohoto visokoct'enjeho nášho pána dopisuvatela na poli naších Národňích Novín, i prosíme ho srd'ečňe, abi i na d'alej v drahocenních dopisoch svojich pokračuvat' ráčiu» (Slovenskje národňje novini. 1845. №41. S 162). 
гелической церкви в Ратковой, годовщины освящения елшавского костела, освящения костела в Каменянах и погребения Штефана Клементиса (общественного деятеля, покровителя и сторонника национального движения) ${ }^{1}$.

Ферьенчик публиковал новостные статьи в «Словацкой национальной газете» (т. I.-III, 1845-1847), а в «Орле татранском» и в зарубежных газетах - тексты, связанные с его профессиональными интересами (метеорология или помология), а также с положением протестантов в Венгрии. В «Новостях Рожнявы» («Rozsnyói Hiradó») также разместил свой небольшой доклад об истории Муранского замка.

В 50-х гг. XIX в. его деятельность была сосредоточена на правовом статусе протестантов в Венгрии. Этот интерес был связан с временным постановлением от 10 февраля 1850 г. для венгерских протестантских церквей, которое лишило их автономии в церковных и образовательных вопросах (свободный выбор церковных и светских настоятелей, разрешение генерального конвента, равноправие нереорганизованных и реорганизованных школ и признание государством их аттестатов) $)^{2}$. По случаю визита императора Франтишека Юзефа в Венгрию в 1852 г. Ферьенчик планировал подать ему письменное обращение с просьбой о возвращении надзирателей и генеральных конвентов и о венгерской школьной системе, подготовленную адвокатом г. Левочи Фабрици и подписанную им от имени всего дистрикта, однако священство воспротивилось такому шагу ${ }^{3}$. В 1855 г. Ферьенчик опубликовал статью о социальном положении вдов евангелических священников и о возможностях помощи их семьям в «Protestantische Jahrbücher für Oesterreich» ${ }^{4}$. К его самым известным работам относится «Ideen für die künftige Gesetzgebung, die Wünsche und gerechten Ansprüche der ungarischen Protestanten betreffend» («Идеи для будущего законодательства, касающиеся желаний и законных требований венгерских протестантов») $)^{5}$, который в свое время был предметом неоднократных дискуссий ${ }^{6}$ В этой работе, в которой Павел Хлебуш находит связь с требованиями «Словацкого престольного просбописа» в церковной сфере ${ }^{7}$, Ферьенчик занимается истоками, ситуацией и возможными решениями неблагоприятного правового положения протестантов в Венгрии. Однако он рассматривает проблему с точки зрения не национальных, а церковных прав: автономии Евангелической церкви, ее финансирования, положения ее школ, финансирования учителей, свободного посещения немецких протестантских университетов, равенства религий, лояльности церкви государству и т. д. Национальный вопрос он затрагивает только в одном месте работы, где, однако, отражается негативное восприятие «ультраславян, сердцам которых ближе славянство, нежели протестантизм» ${ }^{8}$. Выбор немецкого языка в качестве языка публикации соотносится с тактикой автора, направленной на получение поддержки немецкоязычной общественности ${ }^{9}$. С другой стороны, рукописная записная книжка Ферьенчика, которая была обнаружена историками

\footnotetext{
${ }^{1}$ CM.: Rizner V. Bibliografia písomníctva slovenského na spôsob slovníka: od najstarších čias do konca r. 1900. Diel prvý, A-F. Turčiansky Sv. Martin, 1929. S. 392.

${ }^{2}$ Rapant D. Slovenské povstanie roku 1848-49. Dejiny a dokumenty. Diel štvrtý: Letná výprava. IV. 1. Bratislava, 1963. S. 618.

${ }^{3}$ Rapant $D$. Slovenské povstanie roku 1848-49. Dejiny a dokumenty. Diel štvrtý: Letná výprava. IV. 1. S. 618, прим. 1165.

${ }^{4}$ Ferientsik S. Sexty und Blaho // Protestantische Jahrbücher Oesterreich. 1855. I Hälfte. Pest, 1855. S. 29-32.

${ }^{5}$ [Ferientsik $S$.]. Ideen für die künftige Gesetzgebung, die Wünsche und gerechten Ansprüche der ungarischen Protestanten betreffend. Eine Denkschrift von F. und F. Wien: Verlagshandlung von Leopold Sommer, 1850.

${ }^{6}$ Biographisches Lexikon des Kaisertums Oesterreich. Vierter Teil. S. 187

${ }^{7}$ Chlebuš $P$. Samuel Ferienčík známy slovenský národný činitel'. S. 138; 144.

${ }^{8}$ [Ferientsik S.]. Ideen für die künftige Gesetzgebung. S. 24.

${ }^{9}$ Chlebuš P. Samuel Ferienčík známy slovenský národný činitel'. S. 144.
} 
литературы совсем недавно, свидетельствует о том, что автор также использовал немецкий язык в частных заметках и размышлениях, связанных с философскими, теологическими и другими вопросами.

Рукописная записная книжка представляет собой аутентичный материал, связанный с рядом культурных, литературных, религиозных и философских явлений своего времени. Она была обнаружена в приходе Евангелической церкови Аугсбургского вероисповедания в Елшаве (администратор прихода магистр Иван Бойна). Заметки Ферьенчика имеют разное содержание и представляют собой размышления о социальных, теологических, философских, исторических, культурных, национальных и других проблемах.

\section{НАУЧНАЯ И ПРОСВЕТИТЕЛЬСКАЯ ДЕЯТЕЛЬНОСТЬ}

Другие опубликованные работы Ферьенчика связаны с его научными и образовательными интересами в сфере метрологии и помологии. В современных словацких, немецких и венгерских периодических изданиях он публиковал не только обычные новостные и публицистические тексты, но также прогнозы погоды, характеристики погоды и метеорологические статьи («Орол Татранский»; т. I, 1845-1846, № 16, 18, 27; т. II, 1846-1847, № 36, 44, 52, 60, 61; т. III, 1847-1848, № 68); «Magyar Hirlap» / «Венгерская новостная газета», т. 4, 1852, №679, 680; «Budapesti Hirlap» / «Будапештская новостная газета», т. 1, 1853, № 185-188; «Домашняя казна», т. II, 1848 и др.; «Gemeinnützige Blätter zur Belehrung und Unterhaltung» / «Общественно полезная образовательная и развлекательная газета», т. 28,1844 и сл.) и работы по помологии («Magyar Gazda» / «Венгерский хозяин», 1842, № 87; «Gazdasági Lapok» / «Экономическая газета», 1853) ${ }^{1}$. Ферьенчик проводил и инструментальные наблюдения за погодой ${ }^{2}$. Помимо метеорологии он также преуспел в области помологии. В 1841-1847 гг. он был директором Черешневого товарищества в Елшаве, чей большой фруктовый сад характеризовался по всей стране как образцовый с точки зрения порядка и разнообразия; он занимался не только выращиванием деревьев, но и различной переработкой и продажей фруктов ${ }^{3}$. В 50-х годах XIX в. он опубликовал в журнале «Gazdasági Lapok» ассортимент из своего сада.

Ферьенчик был активным также в области продвижения и распространения словацких книг и других изданий (включая «Словацкую национальную газету» и «Орла Татранского») ${ }^{4}$. Он был одним из первых акционеров «Словацкой национальной газеты» ${ }^{5}$ Из произведений авторов старшего поколения он распространял работы Яна Голлого 6 .

\footnotetext{
${ }^{1}$ Данные работ по помологии указаны по изданию Rizner $V$. Bibliografia písomnístva slovenského na spôsob slovníka. Diel prvý, A-F. S. 392.

${ }^{2}$ Неизвестно, какие именно метеорологические элементы он измерял и были ли его измерения систематическими, но определенно в 1846 г. он наблюдал температуру воздуха и, вероятно, осадки. Petráś, M. Z dejín meteorológie na Slovensku do roku 1918 // Z dejín vied a techniky na Slovensku VII. Bratislava, 1974. S. 189. В 1852 г. Центральный метеорологический институт в Вене прислал ему метеорологические приборы; см. Biografický lexikón Slovenska II (C-F). Martin 2004. S. 549; Krška K. Šamaj F. Dějiny meteorologie v českých zemích a na Slovensku. Praha, 2001. S. 158.

${ }_{3}^{3}$ Szinnyei J. Magyar írók élete és munkái a Magyar Tudományos Akadémia megbizásából 3. köt. Fa-Gwóth. Col. 424.

${ }^{4}$ Cм., напр.: Chlebuš P. Samuel Ferienčík známy slovenský národný činitel'. S. 129; Podol'ský [Paullny-Tóth V.] Samuel Ferjenčík // Sokol: časopis pre zábavu a poučenie. 1864. № 10. S. 185.

${ }^{5}$ C.Z. Michal Mil. Hodža : farár cirkve evang. A.V. Vrbicko-St. Mikulášskej v Liptove, rytier rádu Františka Josefa, a Vikár požonskej Superintendencie. (Pokračovanie a dokončenie) // Sokol. Časopis pre zábavu a poučenie. 1863 . №20. S. 461.

${ }^{6}$ Gál V. Samuel Ferienčík // Evanjelický posol spod Tatier. 1980. №6. S. 187.
} 


\section{РАЗВИТИЕ ОБРАЗОВАНИЯ И ЦЕРКВИ}

Вилиам Паулины-Тот указывает, что Ферьенчик работал «с максимальным усердием в своем священническом служении и выступал за благоустойство церкви и школ, которые находились под его присмотром» ${ }^{1}$. О том, что он способствовал развитию образования в месте, где работал, свидетельствует высокий уровень елшавской школы². В 50-х гг. XIX в. деятельность Ферьенчика была сосредоточена на правовом статусе протестантов в Венгрии, о чем свидетельствует его неудавшаяся инициатива подать императору петицию о возвращении надзирателей и генеральных конвентов, а также о венгерской школьной системе. В связи с этом особо важна работа «Ideen für die künftige Gesetzgebung, die Wünsche und gerechten Ansprüche der ungarischen Protestanten betreffend». В 1855 г. Ферьенчик опубликовал статью о социальном положении вдов евангелических священников и о возможностях помощи их семьям в «Protestantische Jahrbücher für Oesterreich» ${ }^{3}$. Ферьенчик, как посланник Потисского дистрикта Евангелической церкви, присутствовал на общих собраниях Общества Густава Адольфа в 1851 г. в Мамбурге и в 1852 г. в Висбадене, чтобы потребовать поддержки церкви и церковным школам; по этому вопросу он трижды ездил в Вену к ипператорскому трону ${ }^{4}$. В этой связи он также упоминается как покровитель Прешовского коллегиума ${ }^{5}$, для которого в 1852 г. в Висбадене он обеспечил финансовую поддержку, в 1853-1855 гг. он в письменной форме сообщил, что ему удалось получить финансовую поддержку из Лейпцига (Германия) и что его письма нашли благоприятный отклик в Нидерландах и Англии 6 . На общее собрание Общества Густава Адольфа в Мамбурге направило Ферьенчика собрание дистрикта от 24-25 апреля 1851 г. в Прешове, чтобы он получил поддержку для бедных евангелических церквейㄱ. В следующем году Ферьенчик предпринял успешную поездку в Берлин; от короля Пруссии он получил 1000 талеров, а от принца - 50 дукатов; полученные деньги в основном он передал школе в Прешове ${ }^{8}$. Среди его заслуг в развитии церкви стоит отдельно упомянуть ремонт елшавской церкви и строительство церковной башни (1833 г.) после пожара в Елшаве (1828 г.).

\section{ПЕТИЦИЯ ПРОТИВ МАНИФЕСТАЙ.М. ГУРБАНА И СЛОВАЦКОЕ НАЦИОНАЛЬНОЕ ВОССТАНИЕ 1848-1849 ГГ.}

Личность Самуила Ферьенчика показывает, что исторические фигуры нельзя воспринимать в черно-белых тонах и что историческая реальность пластична и многомерна. Это становится очевидным, если взглянуть на противоречи-

\footnotetext{
${ }^{1}$ Podol'ský [Paullny-Tóth V.] Samuel Ferjenčík. S. 184

${ }^{2}$ Chlebuš $P$. Samuel Ferienčík známy slovenský národný činitel'. S. 138.

${ }^{3}$ Ferientsik S. Sexty und Blaho. S. 29-32.

${ }^{4}$ Podol'ský [Paullny-Tóth, V.] Samuel Ferjenčík. S. 184; Szinnyei J. Magyar írók élete és munkái a Magyar Tudományos Akadémia megbizásából 3. köt. Fa-Gwóth. Col. 424.

${ }^{5}$ Biografický lexikón Slovenska II. Martin 2004. S. 549; Hleba E. K slovenským problémom kolégia v prvej polovici 19. storočia. // Prešovské kolégium v slovenských dejinách. Košice: Východoslovenské vydavatel'stvo, 1967. S. 112-113.

${ }^{6}$ Hleba E. K slovenským problémom kolégia v prvej polovici 19. storočia. S. 112.

${ }^{7}$ В связи с этим Дэниел Рапант отмечает отсутствие дальнейших отчетов о результатах посольства. Ферьенчику был выдан паспорт без возражений с согласия комитатского начальника, со справкой о том, что он никоим образом не участвовал в революции и не делал после ее поражения ничего, что могло бы поставить под сомнение его лояльность (Rapant D. Slovenské povstanie roku 1848-49. Dejiny a dokumenty. Diel štvrtý: Letná výprava. IV. 1. S. 622, прим. 1181).

${ }^{8}$ Rapant D. Slovenské povstanie roku 1848-49. Dejiny a dokumenty. Diel štvrtý: Letná výprava. IV. 1. S. 622, прим. 1182.
} 
вые аспекты его деятельности, которые включают, помимо его участия в споре о характере литературного язука, его участие в выступлении против манифеста Й.М. Гурбана «Brat’ja Slováci» («Братья словаки») от 1848 г., а также и против словацкого восстания в 1848-1849 гг. Эти взгляды и деятельность Ферьенчика находят противоречивые оценки: от предположений Павела Хлебуша о том, что он был вынужден сделать это под давлением обстоятельствам и целенаправленного-воздействия венгерской церкви и комитатской верхушки ${ }^{1}$ до предположений Йозефа Деммеля о том, что речь шла об активном выражении индивидуальных политико-патриотических и в то же время антинациональных взглядов Ферьенчика $^{2}$. В первом случае речь идет о елшавском заявлении приходских священников и школьных учителей гемерского сеньората: 18 мая 1848 г. они, «как венгерские граждане, а также церковные чиновники», ссылаясь на свои обязательства перед «дорогой страной», для которой они хотели быть «благодарными сыновьями», высказались за мир и взаимопонимание между различными венгерскими национальностями и дистанцировались от заявления Гурбана, якобы нарушающего его и поддерживающего тенденции, ведущие к ненависти, неприязни и распаду ${ }^{3}$. Участие Ферьенчика в заявлении следует рассматривать в более широком контексте. Его подписали известные культурные деятели Йонатан Доброслав Чипка, Павол Добшинский, Самуил Ройсс, Людовит Ройсс или Само Томашик ${ }^{4}$. Ситуацию можно охарактеризовать таким образом: в словацком движении кристаллизовалось несколько течений, в том числе умеренная часть, целью которой было частичное признание национальных прав в рамках венгерского монизма (представители старшего поколения, за исключением Коллара, Кузмани, Халупковцев, Фейерпатаки), и радикальная часть, которая стремилась достичь большей независимости и ориентировалась при этом на Австрию; Ферьенчик проявил себя как сторонник первой группы ${ }^{5}$. К важным контекстуальным факторам относятся патриотические взгляды комитатских деятелей; они, вероятно, в значительной степени способствовали формированию взглядов, которые были публично представлены разоблаченными служителями гемерской церкви (Ферьенчик в то время выступал как ее консеньер), а также представителями городской интеллигенций.

Среди других спорных моментов в жизни Ферьенчика - его участие во время в восстании 1848-1849 гг., в частности то, что весной 1849 г. он выступил против словацких добровольцев. Оценки его действий противоречивы, как и его выступления против манифеста Гурбана. В то время как Йозеф Деммель считает в этой связи, что «мадьяронство» было «политической позицией, личной национальной стратегией», благодаря которой «он был полностью исключен из штуровского национального движения» ${ }^{7}$, Павел Хлебуш заявляет, что Ферьенчик был вынужден поступать таким образом ${ }^{8}$. Что, по его мнению, «не делали комитатские господа, то рьяно выполняли местные деятели, прежде всего бурмистр Елшавы Ян Малле-

${ }^{1}$ Chlebuš $P$. Samuel Ferienčík známy slovenský národný činitel'. S. 141.

${ }^{2}$ Demmel J. Rok 1848 a Slováci. S. 79; 84

${ }^{3}$ Steier L. A tót nemzetiségi kérdés 1848-49-ben. II. Okmánytár. Budapest, 1937. O. 54-55.

${ }^{4}$ Steier L. A tót nemzetiségi kérdés 1848-49-ben. II. Okmánytár. Budapest, 1937. O. 55.

${ }^{5}$ Chlebuš P. Samuel Ferienčík známy slovenský národný činitel'. S. 140-141; RAPANT: Slovenské povstanie roku 1848-49. Dejiny a dokumenty. Diel prvý: Slovenská jar 1848. I. 1. Turčiansky sv. Martin: Matica slovenská, 1937. S. 310; porov. tiež RAPANT: Slovenské povstanie roku 1848-49. Dejiny a dokumenty. Diel druhý: Povstanie septembrové. II. 2. Turčiansky sv. Martin: Matica slovenská,1948. S. 611.

${ }^{6}$ Cp. Chlebuš $P$. Samuel Ferienčík známy slovenský národný činitel'. S. 140.

${ }^{7}$ Demmel J. Rok 1848 a Slováci. S. 79; 84.

${ }^{8}$ Chlebuš P. Samuel Ferienčík známy slovenský národný činitel'. S. 142-143. 
тер»; «не выбирая способа и недостойно для человека его позиции вынудили бегать по Мурани с флагом Кошута и кричать, чтобы Божье благословение не сошло на тех, кто не встал на сторону Кошута» ${ }^{2}$. По данным Даниэля Рапанта, это заявление было сделано на комитатском заседании и звучало оно так: "Aki Kossuthal nem tart, arra Isten áldása na száljon» («Кто не с Кошутом, пусть не получит Божьего благословения») ${ }^{2}$. Предположения Хлебуша материально не обоснованы, и их трудно принять. Однако позиция местной елшавской элиты, несомненно, также способствовала формированию позиции Ферьенчика. Карол Борик, который расследовал жалобы на предполагаемые бесчинства словацких добровольцев в Елшаве, утверждает в своих мемуарах, что «Елшава была известна как полностью кушутовски настроенная и мятежная» ${ }^{3}$. Он описывает ход собрания городского совета, на котором присутствовал и С. Ферьенчик, но якобы «не присутствовал ни один словацкий патриот» ${ }^{4}$ Ферьенчик «встал <...> и сказал, что он решительно не принимает и отвергает выражение нелояльности города Елшава (императору; примечание авторов. - М.Б., А.Б.)», на что якобы Борик «напомнил о его героизме у Мурана, где под красным флагом и он, как борец с императорским (!), доказал свою лояльность, сказав подопечным, что, если у Елшавы не будет более убедительного защитника ее лояльности, чем пастор Ферьенчик, в таком случае мне очень жаль город» ${ }^{5}$.

Еще один важный фактор, который следует учитывать при поиске детерминантов поведения Ферьенчика, - это его интересы в церковной сфере и позиция церковной власти, особенно суперинтенданта Потиского района Михала Пака (1795$1859)^{6}$. Согласно заявлению приходского священника в Сучанах Андрея Годжи (примерно середина июня 1849 г.), «особенно мятежный фанатизм Пака граничит с безумием. Таким образом, повстанческое поведение Ферьенчика, или священнослужителя в гемерской Елшаве, которому предстояло повести фанатичную толпу людей против фельдмаршала Фогеля ${ }^{7}$ под красным флагом» ${ }^{8}$. Революционные события 1848-1849 гг. противоречили и собственным интересам Ферьенчика в церковной сфере. Венгерский протестантизм воспринимался как источник вечного противостояния в Венгрии, а также как причина восстания в 1848-1849 гг. ${ }^{9}$ Хотя чуть позже Ферьенчик и пытался исправить этот образ, о чем свидетельствует ряд отрывков в работе «Ideen für die künftige Gesetzgebung, die Wünsche und gerechten Ansprüche der ungarischen Protestanten betreffend».

И последнее, но не менее важное: участие Ферьенчика в восстании следует рассматривать в контексте взглядов старых словацких писателей, которые - в целом - поддерживали венгерский монизм. Даниэл Рапант указывает, что «помимо

\footnotetext{
${ }^{1}$ Chlebuš $P$. Samuel Ferienčík známy slovenský národný činitel'. S. 142.

${ }^{2}$ Rapant $D$. Slovenské povstanie roku 1848-49. Dejiny a dokumenty. Diel piaty: Doplnky. Opravy. Súhrny. Mená a veci. V. 1. Bratislava, 1967. S. 146-147.

${ }^{3}$ Rapant D. Slovenské povstanie roku 1848-49. Dejiny a dokumenty. Diel štvrtý. Letná výprava. IV. 2. Bratislava, 1961. S. 506.

${ }^{4}$ Rapant D. Slovenské povstanie roku 1848-49. Dejiny a dokumenty. Diel štvrtý. IV. 2. S. 507.

${ }^{5}$ Rapant $D$. Slovenské povstanie roku 1848-49. Dejiny a dokumenty. Diel štvrtý. IV. 2. S. 507. После городского совета и последующих обысков в домах Борик задержал Маллетера за хранение военного снаряжения для отрядов Кошута и отправил его в наручниках в штаб повстанцев в город Римавска-Собота (см. там же: С. 507-508).

${ }^{6}$ Кстати, сын Пака был личным другом Шандора Петефи.

${ }^{7}$ Anton Vogel.

${ }^{8}$ Rapant D. Slovenské povstanie roku 1848-49. Dejiny a dokumenty. Diel tretí. Zimná výprava. III. 3. Bratislava, 1958. S. 489.

${ }^{9}$ Rapant D. Slovenské povstanie roku 1848-49. Dejiny a dokumenty. Diel štvrtý. IV. 1. S. 619.
} 
сторонников нового общественного мнения еще долго появляются приверженцы старого политико-национального дуализма, не говоря уже о последователях венгерского патриотического монизма, представленных (за некоторыми исключениями, такими, как Коллар, Кузмани, Халупковци, Фейерпатаки) в основном так называемыми старословаками (Себерини, С. Ферьенчик и др.), и даже (исключительно в венгерском понимании) очевидными отступниками» ${ }^{1}$. Более подробную оценку в таком же духе сформулировал уже Й.М. Гурбан в «Коледе, Календаре на обычный 1851 год», писавший о том, что старшая литературная школа за исключением Коллара, Халупки, Кузмани и т. д. стала словацкой школой Кошута; в качестве примера он называет Себерини, Ферьенчика и др. ${ }^{2}$

В связи с выступлением в 1848 г. на стороне кошутовцев Ферьенчик оказался под следствием. Судебное расследование его деятельности началось в январе 1852 г., причем говорилось о двух правонарушениях: «предполагаемом несогласии с временным патентом, выданным императором, и выражением согласия с Кошутом в “муранском” выступлении Ферьенчика»${ }^{3}$ Однако расследование в отношении Ферьенчика было прекращено.

Рассматривая публичную деятельность Ферьенчика, можно отметить изменение его позиции во второй половине 40-х гг. ХІХ в. Это касается главным образом его стратегии участия в национальных вопросах. Ферьенчик не упускал из виду национальный интерес, но он не был на первом месте в рейтинге его приоритетов. В связи с этим можно сослаться на оценку его усилий повлиять на кадровые вопросы в Прешовском колегиуме в 50-х гг. XIX в.: «Позиция Ферьенчика здесь оказалась довольно осторожной, и кажется, что даже в вопросах словацкой ориентации он уже не был явно на стороне прогрессивных концепций в то время. Из его заявления об отдельных кандидатах следует, <...> что он предпочел профессиональное рвение и баланс характера как основные условия будущей успешной пастырской деятельности всему остальному и, следовательно, возможно, также сознательному словацкому сознанию» ${ }^{4}$. В пояснении Яна Владимира Ормиса в биографии Людовита Штура (произведение Гурбана) говорится, что Ферьенчик «после революции значительно охладел к национальным вопросам» ${ }^{5}$. В результате возникли определенные противоречия, которые повлияли на восприятие личности Ферьенчика в национальном движении, хотя в целом оценка его деятельности остается положительной. Например, Вилиам Паулины-Тот подчеркивает важность «Словацкого престольного просбописа», который был «после тысячелетнего сна первым признаком жизни словацкого народа, и с этой искры шесть лет спустя разгорелся огонь словацкого восстания как яркий протест нации против суверенитета одной и нескольких нации над другими, но в условиях 1848 года как живой протест Словакии против господства Венгрии» ${ }^{6}$. Он утверждает, что Ферьенчик был «всесторонне образованным человеком, отличающимся

\footnotetext{
${ }^{1}$ Rapant D. Slovenské povstanie roku 1848-49. Dejiny a dokumenty. Diel prvý: Slovenská jar 1848. I. 1. Turčiansky sv. Martin, 1937. S. 310.

2 Ян Клсак, Эмануэль Вилем Шимко, Кароль Адамиш, Ондрей Горислав Ланштяк, Штефан Лаунер, Лукаш Мачай, Фердинанд Пеликан, Ондрей Костелный; Rapant D. Slovenské povstanie roku 1848-49. Dejiny a dokumenty. Diel druhý: Povstanie septembrové. II. 2. Turčiansky sv. Martin, 1948. S. 611.

${ }^{3}$ Chlebuš $P$. Samuel Ferienčík známy slovenský národný činitel'. S. 145.

${ }^{4}$ См.: Hleba E. K slovenským problémom kolégia v prvej polovici 19. storočia. S. 112-113; ср. также Rapant $D$. Slovenské povstanie roku 1848-49. Dejiny a dokumenty. Diel štvrtý. IV. 1. S. 622; прим. 1182 и указанные там источники.

${ }^{5}$ Hurban J.M. L'udovít Štúr - Rozpomienky. Bratislava, 1959. S. 874; пояснения к стр. 262.

${ }^{6}$ Podol'ský [Paullny-Tóth V.] Samuel Ferjenčík. S. 184-185.
} 
специальными знаниями даже в естественных науках; при этом он был человеком благородного характера и верным сыном словацкого народа» ${ }^{1 .}$

\section{ЗАКЛЮЧЕНИЕ}

Самуил Ферьенчик относится к несправедливо забытым личностям словацкой культурной истории. При объективной оценке нельзя отрицать его значимость не только в словацком, но также в венгерском и австрийском контекстах. Своей деятельностью он внес значительный вклад в повышение культурного, образовательного, духовного и социального уровня словацкого населения Венгерского Королевства. Ферьенчик принадлежал к личностям, которые его современники не могли игнорировать, хотя они не разделяли всех его взглядов. То, что после смерти он не стал непререкаемым авторитетом в словацкой культурной истории, обусловлено его отношением к вопросам литературного языка, манифесту Й.М. Гурбана и, главным образом, его поведением во время Словацкого национального восстания 1848-1949 гг. Адекватная интерпретация его позиции должна учитывать ценностное разнообразие современной культурной элиты (в которой национальный фактор прежде не был доминирующим) и поколенческую специфику, в контексте которой его действия и взгляды кажутся закономерными ${ }^{2}$.

\section{Л И Т РАT У PA / REFERENCES}

Arany J. Arany János elbeszélő költeményei. Első kötet. Toldi. Budapest: Kiadja Ráth Mór, 1883. 654 o.

Biografický lexikón Slovenska II (C-F). Martin: Slovenská národná knižnica, 2004. 696 s.

Biographisches Lexikon des Kaiserthums Oesterreich. Vierter Theil. Wien: Drund und Verlag der typogr.-literar.-artist. Anstalt (L.C. Zamarski, C. Dittmarsch \& Comp.), 1858. 415 s.

Botto J. Michal M. Hodža. Životopisný nákres. Turčiansky Sv. Martin: Kníhtlačiarsky účastinársky spolok, 1911. $66 \mathrm{~s}$.

Botto J. Slováci: vývin ich národného povedomia: dejepisný nákres. Turčiansky Sv. Martin: Vydanie Kníhkupecko-nakladatel'ského spolku, 1906. 263 s.

C.Z. Michal Mil. Hodža : farár cirkve evang. A.V. Vrbicko-St. Mikulášskej v Liptove, rytier rádu Františka Josefa, a Vikár požonskej Superintendencie. (Pokračovanie a dokončenie) // Sokol. Časopis pre zábavu a poučenie. 1863. №20. S. 485-463.

Chlebuš P. Samuel Ferienčík známy slovenský národný činitel' // Vlastivedné štúdie Gemera č. 4. Martin: Osveta, 1986. S. 128-148.

Demmel J. Rok 1848 a Slováci // Rozštiepená minulost'. Kapitoly z histórie Slovákov a Mad’arov. Budapest: Nadácia Terra Recognita, 2008. S. 77-86.

[Ferientsik S.]. Ideen für die künftige Gesetzgebung, die Wünsche und gerechten Ansprüche der ungarischen Protestanten betreffend. Eine Denkschrift von F. und F. Wien: Verlagshandlung von Leopold Sommer, 1850. $46 \mathrm{~s}$.

Ferientsik S. Sexty und Blaho // Protestantische Jahrbücher Oesterreich. Unter Mitwirkung mehrerer protest. Theologen und Schulmänner herausgegeben von Victor Hornyánsky. 1855. I Hälfte. Pest: Bei Gustav Heckenast, 1855. S. 29-32.

\footnotetext{
${ }^{1}$ Podol'ský [Paullny-Tóth V.] Samuel Ferjenčík. S. 185. Кстати, влиянию Ферьенчика приписывается и пробуждение национальных чувств его племянника, известного словацкого журналиста и писателя Микулаша Штефана Ферьенчика; см.: Škultéty J. Mikuláš Št. Ferienčík // Slovenské Pohl’ady. 1881. № 3. S. 234.

${ }^{2}$ Статья подготовлена в рамках проекта VEGA № 2/0136/21 « Literárnohistorické, kultúrnohistorické a edičné spracovanie rukopisnej poznámkovej knihy Samuela Ferjenčíka».
} 
Ferjenčík S. XXVIII. Slowo lásky ku Břetislawským Nowinám // Hlasowé o potřebě jednoty spisowného jazyka pro Čechy, Morawany a Slowáky. W Praze: W kommissí u Kronbergra i Riwnáče, 1846. S. 214-216.

Ferjenčík S. Zlomka z Meteorologie // Domová pokladňica kalendár na rok prjestupní 1848. Vidáva Daniel Lichard. Ročňík druhí. Skalica: písmom a tlačivom Fraňa Xav. Škarnicla a Sinou, [1848]. S. 52-57.

Gál V. Samuel Ferienčík // Evanjelický posol spod Tatier. 1980. № 16. S. 187.

Hleba E. K slovenským problémom kolégia v prvej polovici 19. storočia. // Prešovské kolégium v slovenských dejinách. Košice: Východoslovenské vydavatel'stvo, 1967. S. 110-114.

Hurban J.M. L'udovít Štúr - Rozpomienky. Bratislava: Slovenské vydavatel'stvo krásnej literatúry, $1959.961 \mathrm{~s}$.

Hurban J.M. L’udovít Štúr. (Pokračovanie) // Slovenské Pohl'ady. 1882. № 3. S. 34-52, $127-$ 151, 242-270, 338-362, 439-452, 533-562.

Kollár J. Odpowěd' Jana Kollára na psaní Ludewíta Štúra ode dne 7 Unora 1846 // Hlasowé o potřebě jednoty spisowného jazyka pro Čechy, Morawany a Slowáky. W Praze: W kommissí u Kronbergra i Řiwnáče, 1846. S. 127-168.

Kollár J. Dielo I. Bratislava: Slovenský TATRAN, 2001. 470 s.

Kollár J. Díla básnická Jana Kollára we dwau djljch. W Budíně: Wytištěna literami Gyuriána a Bágo, 1845. [335], 58, [2] s.

Kollár J. Sláwy dcera. W Pešti: tiskem Trattnera a Károliho, 1832. [323] s.

Kollár $J$. Wýklad čili Přjmětky a wyswětliwky ku Sláwy dceře. W Pešti: tiskem Trattnera a Károliho, 1832. $528 \mathrm{~s}$.

Krška K. - Šamaj F. Dějiny meteorologie v českých zemích a na Slovensku. Praha: Univerzita Karlova v Praze - Nakladatelství Karolinum, 2001. 565 s.

Orol Tatranskí, т. 2, 1846-1847. № 52.

Petráš M. Z dejín meteorológie na Slovensku do roku 1918 // Z dejín vied a techniky na Slovensku VII. Bratislava: VEDA, Vydavatel'stvo SAV, 1974. S. 169-204.

Podol'ský [Paullny-Tóth V.] Samuel Ferjenčík // Sokol: časopis pre zábavu a poučenie. 1864. № 10. S. 183-185.

Rapant $D$. Slovenské povstanie roku 1848-49. Dejiny a dokumenty. Diel piaty: Doplnky. Opravy. Súhrny. Mená a veci. V. 1. Bratislava: Vydavatel'stvo Slovenskej akadémie vied, 1967. $443 \mathrm{~s}$.

Rapant D. Slovenské povstanie roku 1848-49. Dejiny a dokumenty. Diel prvý: Slovenská jar 1848. I. 1. Turčiansky sv. Martin: Matica slovenská, 1937. 404 s.

Rapant $D$. Slovenské povstanie roku 1848-49. Dejiny a dokumenty. Diel druhý: Povstanie septembrové. II. 2. Turčiansky sv. Martin: Matica slovenská, 1948. 748 s.

Rapant D. Slovenské povstanie roku 1848-49. Dejiny a dokumenty. Diel štvrtý: Letná výprava. IV. 1. Bratislava: Vydavatel'stvo Slovenskej akadémie vied, 1963. 779 s.

Rapant D. Slovenské povstanie roku 1848-49. Dejiny a dokumenty. Diel štvrtý. Letná výprava. IV.2. Bratislava: Vydavatel'stvo SAV, 1961. 543 s.

Rapant $D$. Slovenské povstanie roku 1848-49. Dejiny a dokumenty. Diel tretí. Zimná výprava. III. 3. Bratislava: Vydavatel'stvo SAV, 1958. $686 \mathrm{~s}$.

Rapant D. Slovenský prestolný prosbopis z roku 1842. 2. diel. Dokumenty. Liptovský Sv. Mikuláš: Tranoscius, 1943. $630 \mathrm{~s}$.

Rizner $V$. Bibliografia písomníctva slovenského na spôsob slovníka: od najstarších čias do konca r. 1900. Diel prvý, A-F. Turčiansky Sv. Martin: Matica slovenská, 1929. 416 s. 
Schröer K.J. Goethe und ein Candidat der Theologie aus Ungarn // Chronik des Wiener Goethe-Vereins. 1889. № 2. S. 7-11

Škultéty J. Mikuláš Št. Ferienčík // Slovenské Pohl’ady. 1881. №3. S. 233-238.

Slovenskje národňje novini. 1845. № 1 .

Steier L. A tót nemzetiségi kérdés 1848-49-ben. II. Okmánytár. Budapest: Magyar Történelmi Társulat, 1937. 787 o.

Szinnyei J. Magyar írók élete és munkái a Magyar Tudományos Akadémia megbizásából 3. köt. Fa-Gwóth. Budapest: Hornyánszky, 1894. 1582 col.

Zelený V. Jan Kollár. Máj: almanah na rok 1862. Praha: I.L. Kober, 1862. S. 1-32.

Сведения об авторах:

\author{
Мартин Браксаторис, \\ доктор философии \\ научный сотрудник \\ Институт словацкой литературы, \\ Словацкая академия наук
}

\author{
Анита Браксаторисова, \\ доктор философии \\ ст. преподаватель \\ философский факультет \\ Университет свв. Кирилла и Мефодия \\ в Трнаве
}

Martin Braxatoris,

Doctor of Philosophy

Researcher

Institute of Slovak Literature,

Slovak Academy of Sciences

martin.braxatoris@gmail.com

Anita Braxatorisová,

Doctor of Philosophy

Assistant Professor

Faculty of Arts

University of Ss. Cyril and Methodius in Trnava

braxatoris@mail.ru 